\title{
CORPORATE SOCIAL RESPONSIBILITY AS A DETERMINANT OF TAX AGGRESSIVITY
}

\author{
RESPONSABILIDADE SOCIAL CORPORATIVA COMO DETERMINANTE DE AGRESSIVIDADE \\ TRIBUTÁRIA
}

Recebido em 14.05.2021 Aprovado em 24.06.2021 Avaliado pelo sistema double blind review DOI: https://doi.org/10.12712/rpca.v15i2.50027

\section{Lohami Rizzi Sevirino}

lohami@gmail.com

Fucape Business School, Vitória/ES, Brasil

0000-0003-2991-2401

\author{
Neyla Tardin \\ neyla@fucape.br \\ Fucape Business School, Vitória/ES, Brasil \\ 0000-0002-8906-3942
}

\begin{abstract}
This research verified whether the practices of corporate social responsibility (CSR) and tax aggressiveness are complementary, substitute or unrelated. A total of 1,081 observations from Brazilian companies listed on B3 were analyzed between 2010 and 2017. The survey used the guidelines of the Global Reporting Initiative (GRI) to measure the degree of CSR. The results show a substitution relationship between companies with a high GRI degree and tax aggressiveness when measured by the differences between accounting profit and taxable profit (BTD), however, this relationship becomes complementary if measured by the total taxes on the amount added (TTVA).

Keywords: Corporate social responsibility; corporate sustainability; tax aggressiveness; Global Reporting Initiative.

\section{Resumo}

Esta pesquisa verificou se as práticas de responsabilidade social corporativa (RSC) e agressividade tributária são complementares, substitutivas ou não relacionadas. Foram analisadas 1.081 observações de empresas brasileiras listadas no B3 entre 2010 e 2017. A pesquisa utilizou as diretrizes da Global Reporting Initiative (GRI) para medir o grau de RSC. Os resultados mostram uma relação de substituição entre empresas com alto grau GRI e agressividade tributária quando medida pelas diferenças entre o lucro contábil e o lucro tributável (BTD), porém, essa relação torna-se complementar se medida pelo total de impostos sobre o valor adicionado (TTVA).

Palavras-chave: Responsabilidade social corporativa; sustentabilidade empresarial; agressividade tributária; Global Reporting Initiative.
\end{abstract}




\section{Introduction}

Corporate Social Responsibility (CSR) has increasingly stimulated research in accounting in recent years, given its impacts on economic performance and the creation of value for companies (Rodrigues \& Nossa, 2017). Although the interest of researchers on the subject is great, the literature still diverges on the existence of an association between CSR and abusive tax planning practices - when companies tend to manipulate taxable profits downwards - in order to pay less taxes.

While theories on CSR suggest that there is a positive or complementary relationship between sustainable practices and conduct of tax aggressiveness (Davis, Guenther, \& Krull, 2016; Hines, 2005), other currents present evidence that there is a negative (substitute) or null relationship between these two practices (Garcia, 2016; Huseynov \& Klamm, 2012; Mackey, Mackey, \& Barney, 2007), which indicates a lack of consensus in the literature on the topic.

In view of this theoretical divergence, this research seeks to verify whether the practices of CSR and tax aggressiveness are complementary, substitute or unrelated. Unlike other surveys that use binary indicators for the Sustainability Index (ISE) of the Brazilian stock exchange as a proxy for CSR (Martinez \& Ramalho, 2017), this study uses different grades of CSR, with high, medium and low commitment of firms to the global accounting disclosure guidelines proposed by the non-governmental organization Global Reporting Initiative (GRI).

GRI proposes disclosure guidelines seeking symmetry and quality of information on the environmental, social and economic impacts of firms (Madalena, Rover, \& Ferreira, 2016; Nossa et al., 2017). Using GRI as a CSR proxy provides (i) the capture of a larger number of companies with CSR-oriented practices; (ii) the identification of the different stages of the CSR adoption movement (high, medium and low degree of commitment) and (iii) international comparability, given that the same guidelines are applied for companies worldwide (Khan, Azizul, Kayeser Fatima, \& Ahmed, 2011; Weber, Koellner, Habegger, Steffensen, \& Ohnemus, 2008).

For the purposes of this research, Brazilian companies listed on B3 between the years 2010 (beginning of the IFRS standard in Brazil) to 2017 were analyzed. To measure companies' tax aggressiveness, BTD (Book-Tax Difference) metrics were used, which show the difference between accounting profit and taxable profit, and TTVA (Total Value Added Tax), which captures the aggressiveness with a broader scope in the Brazilian context, considering not only taxes on profits, but also taxes on revenues.

The results of this study, obtained through linear regression with fixed effect by company and time, validate the hypothesis of substitution and show that CSR practices are negatively associated with tax aggressiveness in companies with an advanced degree of sustainability disclosure when tax aggressiveness is measured by BTD. However, when this relationship is analyzed by adding not only direct taxes, but also indirect taxes on profit - measured by TTVA, the results show that CSR is positively related to tax aggressiveness, validating the hypothesis of complementarity in companies with a high degree of disclosure. This relationship, withal, becomes insignificant when companies have an intermediate, beginner or incomplete GRI report.

The conflicting evidence between the results, perceived in the relationship of the high GRI degree with the BTD and TTVA tax aggressiveness proxies, may be associated with a mechanism of managerial opportunism, given that companies may be more sensitive to the risk of detecting more aggressive practices to avoid taxes when such practices are applied in direct taxes on profit (Income Federal Tax), than in indirect taxes (Sales Tax). In general, direct taxes are more evident in discussions about abusive tax planning than indirect taxes (Mocivuna, Thompson, \& Silva, 2019), although billing taxes represent a relevant part of the Brazilian tax burden (Motta \& Martinez, 2015). 


\section{Theoretical Framework}

\section{Corporate Social Responsibility (CSR)}

The sustainable development of a company is guided by the adoption of practices that seek to mitigate the negative effects of its operation on society and the environment over time (Mackey, Mackey, \& Barney, 2007).

This interaction of economic, social and environmental aspects in management policies brings relevant results in the context of accounting, given that there is evidence that companies concerned with environmental and social issues enjoy a higher degree of growth, return on equity and gain in reputation before the market (Crisóstomo \& Oliveira, 2016; Orsato, Garcia, Mendes, \& Monzoni, 2015; Pereira, Stocker, Mascena, \& Boaventura, 2020; Weber, Koellner, Habegger, Steffensen, \& Ohnemus, 2008).

Based on these findings, the disclosure of accounting information by socially responsible companies becomes relevant for the community in general, as predicted Gray, Owen e Maunders (1983). If in order to acquire public legitimacy, and thus guarantee its long-term survival, it is necessary for the company to communicate with society about the economic, social and environmental policies it adopts, it is clear that this communication needs to be sufficiently clear and transparent.

Following this logic, the American non-governmental organizations Coalition for Environmentally Responsible Economies (CERES) and United Nations Environment Program (UNEP) created the Global Report Initiative (GRI) in 1997, launching a guideline for the preparation of sustainability reports with the aim of objective to lead companies to standardize the disclosure of accounting information (GRI, 2011).

The GRI guidelines refer to indicators that provide information on governance, strategy and vision, economic, social, environmental performance and several other areas of organizations, through a coherent and practical structure, available to different companies in different scenarios (GRI, 2011). The fact that several organizations participate in the governance structure and drafting of guidelines, such as business groups, governments, consultants, academia, workers and class associations, makes GRI a global and reliable measure of CSR (Madalena, Rover, \& Ferreira, 2016; Nossa et al., 2017; Weber et al., 2008).

\section{Tax aggressiveness}

Theoretical studies suggest that the payment of taxes may reduce the investment of companies and, in this perspective, companies would look for options that provide greater investment capacity to the detriment of the tax burden (Hines, 2005). Thus, Hanlon and Heitzman (2010) define tax aggressiveness as being the whole set of techniques used by companies that aim to reduce the tax burden.

Following this definition, several studies in the literature seek to verify which characteristics are decisive in the decision of the managers for a more aggressive policy in the search for the reduction of taxes. As an example of the diversity of topics studied, Lanis and Richardson (2011) stand out, indicating that the participation of external members in companies reduces the propensity of tax avoidance practices, and Hanlon and Slemrod (2009) who studied the effects of fiscal aggressiveness in the company stock price.

Still on the empirical studies in this area, statistical evidence suggests the association of the tax aggressiveness of companies with characteristics such as corporate governance, company size, financial constraint, cost planning, internationalization, business strategies, tax havens, intangible assets and the business environment. (Huang, Lobo, Wang, \& Xie, 2016; Kubick, Lynch, Mayberry, \& Omer, 2014). 


\section{Corporate social responsibility and tax aggressiveness}

Discussions on the theory of steakeholders suggest that, in order to fulfill their social responsibilities and gain legitimacy from society's stakeholders, companies should engage in less aggressive tax avoidance practices (Kim, Park, \& Wier, 2012). This is because, for some lines of study, the management of taxable profit downwards is seen as a non-legitimate practice, which would culminate in a reputation cost for the firms that adopt it (Lanis \& Richardson, 2011).

This negative repercussion of companies' engagement in aggressive tax planning activities was noted in the empirical study by Hanlon and Slemrod (2009), who found evidence that a company's stock price decreases through disclosure of its involvement in policies more aggressive tax planning. Under these arguments, to the extent that companies would increase their degree of engagement in activities, and disclosure of CSR, the less they would tend to manage taxes down (Lanis \& Richardson, 2011; Waller \& Lanis, 2009).

In line with the theory of Mackey et al. (2007), empirical research shows that companies with corporate social responsibility practices tend to have their tax aggressiveness reduced (Garcia, 2016; Huseynov \& Klamm, 2012; Martinez \& Ramalho, 2017).

If adopting CSR practices contributes to the public legitimacy of companies, and engaging in more aggressive fiscal policies goes against the defended CSR concepts, the practices act as substitutes in order to maximize accounting profit and minimize taxable profit, thus, the substitution hypothesis is that socially responsible companies are less tax aggressive than the others (Lanis \& Richardson, 2011; Slemrod, 2004).

The use of CSR practices as a complementary tool to the practices of tax aggressiveness may be due to the fact that corporations involved in CSR have greater potential for building lobbying before the public power, being able to enjoy tax incentives that they would not have had without the benefits of economic growth and of reputation arising from involvement with CSR (Davis et al., 2016; Schepers, 2010).

The propensity to practice tax lobbying can be motivated by the low efficiency of public management in the application of resources, thus, the payment of taxes can be seen as a limiter for the growth of companies, a motivational factor for the search for strategies to reduce taxes (Davis et al., 2016; Hines, 2005; Lanis \& Richardson, 2011).

Empirical research has found that companies with a higher level of CSR are more tax aggressive (Davis et al., 2016; Landry, Deslandes, \& Fortin, 2013). Therefore, considering that companies see that part of the resources destined to pay taxes could be better used in their possession than that of the public authorities, and use the benefits of CSR as one of the tools to minimize the tax burden, the hypothesis of complementarity is that socially responsible companies are more aggressive than others.

\section{Method}

This work has a quantitative, descriptive and longitudinal approach, using secondary data. The data were collected in the Economatica ${ }^{\circledR}$ database, on the Brasil Bolsa, Balcão (B3) website, and on the database provided by the Global Reporting Initiative (GRI). The final sample was composed of Brazilian companies listed on the B3 stock exchange from 2010 to 2017. The initial year chosen is due to the period when the effects of standardizing Brazilian accounting standards with the standards of the International Financial Reporting Standards (IRFS) began.

Companies in the finance and insurance sector were eliminated from the initial sample, with 5,240 observations, given that the degree of regulation and economic interpretation are different from other companies, and those observations that presented missing values for the study variables. Table 1 shows the sample selection process until the 1,081 observations used in this research remain. 
Table 1

Sample selection

\begin{tabular}{ll}
\hline Description & Observações \\
\hline Brazilian companies listed on B3 between 2010 and 2017 & 5240 \\
(-) Companies in the Finance and Insurance sector & -480 \\
(-) Companies without information on assets in the period & -2.577 \\
(-) Duplicate companies and companies without information for the variables & -1.102 \\
(=)Number of used observations & 1.081 \\
\hline
\end{tabular}

Note: Table 1 shows the selection of the sample's observations. The initial year of 2010 is due to the period of beginning of the effects of the standardization of Brazilian accounting standards with IFRS, and the final year of 2017 is due to the fact that it is the most recent year for the collection of data provided by the GRI, fundamental data for the construction of the variables of interest.

Source: prepared by the author, based on data from Economatica.

To verify the association between corporate social responsibility practices and the tax aggressiveness of Brazilian companies listed in B3, a multiple linear regression model was proposed for panel data with fixed effect by companies and year, and robust errors.

Following the regression model of the study by Davis, Guenther and Krull (2016), this study proposed to verify the correlation of different degrees of corporate social responsibility practices of Brazilian companies with tax aggressiveness, an adaptation as shown below.

Regression Model:

TAX_AGG $G_{i, t}$

$=\beta_{0}+\beta_{1} G R I_{-}$Avançado ${ }_{i, t}+\beta_{2}$ GRI_Intermediário $_{i, t}+\beta_{3}$ GRI_Iniciante $_{i, t}+\beta_{4}$ GRI_Incompleto $_{i, t}$

$+\beta_{5} R O A_{i, t}+\beta_{6} L E V_{i, t}+\beta_{7} P P E_{i, t}+\beta_{8} S_{I Z E_{i, t}}+\beta_{9} C A S H_{i, t}+\beta_{10} L_{O S S_{i, t}}+\varepsilon_{i, t}$

Table 2 below shows the definition of the variables that make up the regression model.

Table 2

Variable Definitions

\begin{tabular}{|c|c|c|}
\hline & Variáveis & Definições \\
\hline \multirow{4}{*}{$\begin{array}{c}\text { TAX_AGG } \\
\text { Tax Aggressiveness }\end{array}$} & \multirow{4}{*}{$\begin{array}{c}\text { BTD - Difference between book } \\
\text { profit and taxable profit. } \\
\text { TTVA - Total Value Added } \\
\text { Taxes }\end{array}$} & $\operatorname{LAIR}(t)-(I R+C S L L$ to be paid $)(t)$ \\
\hline & & 0,34 \\
\hline & & Total DVA taxes $(t)$ \\
\hline & & $\overline{\text { Total Value Added DVA }(t)}$ \\
\hline \multirow{4}{*}{$\begin{array}{c}\text { CSR } \\
\text { Corporate Social } \\
\text { Responsibility }\end{array}$} & GRI_high & $\begin{array}{c}1 \text { for accredited companies }(\mathrm{A}, \mathrm{A}+\text {, In accordance } \\
\text { Comprehensive) and } 0 \text { for the others. }\end{array}$ \\
\hline & GRI_medium & $\begin{array}{c}1 \text { for accredited companies }(\mathrm{B}, \mathrm{B}+\text {, In accordance Core }) \\
\text { and } 0 \text { for the others. }\end{array}$ \\
\hline & GRI_beginner & $\begin{array}{c}1 \text { for accredited companies }(\mathrm{C}, \mathrm{C}+) \text { and } 0 \text { for the } \\
\text { others. }\end{array}$ \\
\hline & GRI_incomplete & $\begin{array}{c}1 \text { for accredited companies (Non-GRI) and } 0 \text { for the } \\
\text { others. }\end{array}$ \\
\hline \multirow{2}{*}{ Profitability } & \multirow{2}{*}{$\mathrm{ROA}$} & Net Profit $(t)$ \\
\hline & & $\overline{\text { Total asset }(t)}$ \\
\hline \multirow{2}{*}{ Leverage } & \multirow{2}{*}{ LEV } & Long - term $\operatorname{debt}(t)$ \\
\hline & & Total asset $(t)$ \\
\hline \multirow{2}{*}{ Capital intensity } & \multirow{2}{*}{ PPE } & Fized Assets $(t)$ \\
\hline & & Total asset $(t)$ \\
\hline Firm size & SIZE & Natural log of Total Assets (t) \\
\hline \multirow{2}{*}{ Cash Level } & \multirow{2}{*}{ CASH } & Cash and cash equivalents $(t)$ \\
\hline & & Tota $\operatorname{asset}(t)$ \\
\hline Financial Health & LOSS & $\begin{array}{l}\text { Indicator that assumes a value of } 1 \text { for companies with } \\
\text { consecutive losses in } t-1 \text { and } t \text {, and } 0 \text { for the others. }\end{array}$ \\
\hline
\end{tabular}


GRI_incomplete were collected in a database provided by GRI. LAIR stands for profit before taxes. IR + CSLL to be paid mean Federal Income Tax to be paid.

Source: prepared by the author

The BTD proxy is extracted from the difference in the calculation of accounting profit to that of taxable profit, and its use in this research is due to being a metric usually practiced in papers of tax aggressiveness. (Dunbar, Higgins, Phillips \& Plesko, 2010).

The TTVA proxy captures not only the taxes on profit, but also the taxes on billing, therefore, capturing tax aggressiveness more comprehensively than traditional metrics (Martinez, 2017). Motta e Martinez (2015) indicate that sales taxes are a large part of the tax burden of Brazilian companies, which makes the use of TTVA relevant because it meets a specific characteristic of the Brazilian tax context.

This study used dummies variables as a proxy for Corporate Social Responsibility, classifying companies based on how complete the information in the sustainability reports was according to the level of GRI structure used. This measure to capture sustainability practices is taken from the list of GRI guidelines (Nossa et al., 2017).

Up to the GRI G3 reporting version, the structure level is built by reporting classification criteria in beginners (C), intermediaries (B) e advanced (A). Submitting the sustainability report for GRI examination, or to an external compliance report, credits the company with a score $(+)$, thus, $\mathrm{C}+, \mathrm{B}+$ or A+. (Madalena et al., 2016). From the reports with the GRI G4 version, published as of 2014, the level of structure started to be classified in a low level of disclosure $(\mathrm{N})$, satisfatóri (In accordance - Core) and understanding (In accordance - Comprehensive) (GRI, 2014).

In order to classify the degree of sustainability disclosure of the companies, the classifications of the reports were compared in high, medium, beginner and incomplete degree, as shown in Table 3.

Table 3

Construction of dummy variables to measure the degree of structure of GRI reports

\begin{tabular}{lll}
\hline \hline \multicolumn{2}{l}{ Classifications up to G3 report version - Reports up to $\mathbf{2 0 1 3}$} & \\
\hline Applied structure level & Description & Variable \\
\hline $\mathrm{A}+, \mathrm{A}$ & Advanced degree & GRI_high \\
$\mathrm{B}+, \mathrm{B}$ & Intermediary degree & GRI_medium \\
$\mathrm{C}+, \mathrm{C}$ & Beginner degree & GRI_beginner \\
Non-GRI & Incomplete degree & GRI_incomplete \\
\hline Classifications from the G4 report version & - Reports from 2014 \\
\hline Applied structure level & Description & Variable \\
\hline In accordance - Comprehensive & Advanced degree & GRI_high \\
In accordance - Core & Intermediary degree & GRI_medium \\
Non-GRI & Incomplete degree & GRI_incomplete \\
\hline
\end{tabular}

Note: Table 3 shows the levels of structures applied in the sustainability reports according to the versions of the GRI guidelines. They assume equal value to those companies that have published a sustainability report in some degree of GRI structure, namely: advanced, intermediate, beginner or incomplete, and 0 for other companies.

Source: prepared by the author based on data from the Global Reporting Initiative.

The control variables used in this research come from studies that indicate them in association with the tax aggressiveness of companies (Davis et al., 2016; Hasan, Al-Hadi, Taylor, \& Richardson, 2017; Martinez \& Martinz, 2016; Motta \& Martinez, 2015). In order to make the sample more uniform, control variables such as return on assets (ROA) were included, given that the study by Hasan et al. (2017) found that more profitable companies tend to avoid paying more taxes.

Following the study by Martinez and Martinz (2016), the control variable for leverage (LEV) was included because it identifies that companies with higher rates of tax aggressiveness are more leveraged. 
Martinez and Salles (2018) identified the cash level associated with tax aggressiveness, therefore, the variable $(\mathrm{CASH})$ was included as a control, and since research also shows that the size of companies (SIZE) is a determinant of tax aggressiveness, this was also included as a control variable (Davis et al., 2016; Dyreng et al., 2008; Motta \& Martinez, 2015).

The variable that measures the degree of financial health of the company (LOSS) was added, as the consecutive low performance in profitability can affect the decisions of managers in the companies' fiscal policy (Lanis \& Richardson, 2011; Loebbecke, Eining, \& Willingham, 1989).

\section{Descriptive Statistics and Correlation Analysis}

Table 4 presents the descriptive statistics of the variables used in the research. The observations of companies that reported GRI reports represent $34.41 \%$ of the sample, with the highest concentration being in companies with an intermediate level, corresponding to $24.32 \%$ of the total sample. These data allow to identify a commitment to the disclosure of sustainable practices, by Brazilian companies with CSR management, when perceiving the disclosure of information within the intermediate level, stage below the maximum degree of disclosure quality.

Table 4

Descriptive statistics

\begin{tabular}{lllllll}
\hline Variable & Average & S-deviation & Min. & Max. & Q1 (25\%) & Q3 (75\%) \\
BTD & $-0,0024$ & 0,10 & $-0,57$ & 0,28 & $-0,01$ & 0.03 \\
TTVA & 0,3004 & 0,25 & $-0,36$ & 1,54 & 0,18 & 0,38 \\
GRI_high & 0,0296 & 0,17 & 0,00 & 1,00 & 0.00 & 0.00 \\
GRI_medium & 0,2432 & 0,43 & 0,00 & 1,00 & 0.00 & 0.00 \\
GRI_beginner & 0,0611 & 0,24 & 0,00 & 1,00 & 0.00 & 0.00 \\
GRI_incomplete & 0,0102 & 0,10 & 0,00 & 1,00 & 0.00 & 0.00 \\
ROA & 0,0268 & 0,10 & $-0,54$ & 0,34 & 0.00 & 0.08 \\
LEV & 0,0342 & 0,23 & 0,01 & 1,55 & 0.19 & 0.44 \\
PPE & 0,2370 & 0,22 & 0,00 & 0,87 & 0.03 & 0.38 \\
SIZE & 14,7990 & 1,75 & 9,43 & 18,79 & 13.58 & 16.00 \\
CASH & 0,0801 & 0,81 & 0,00 & 0,66 & 0.02 & 0.12 \\
LOSS & 0,2488 & 0,43 & 0,00 & 1,00 & 0.00 & 0.00 \\
\hline
\end{tabular}

Note: Table 4 shows the means, standard deviations, minimums, maximums, quartiles 1 and 3 of the variables. After treatments, the original sample, which was 5,240 observations for the period 2010 to 2017 extracted from Economática ${ }^{\circledR}$, left a total of 1,081 observations for all variables. The BTD variable was divided by the total assets of each company to allow greater comparability. Companies with no assets in the period, with duplicate information for the variables, and companies in the finance and insurance sector were excluded. The variables were 1\% winsorized. The definitions of the variables are shown in Table 2.

Source: prepared by the author, outputs from the Stata software ${ }^{\circledR}$.

The variables ROA, LEV, PPE, SIZE, CASH and LOSS present acceptable means and standard deviations, compatible with previous studies (Lanis \& Richardson, 2011; Martinez \& Ramalho, 2017; Motta \& Martinez, 2015).

Table 5, in turn, shows the results of Pearson's correlation. There is a positive correlation between the variable GRI_medium with BTD at the significance level of $1 \%$, thus suggesting that companies with higher levels of socially responsible practices tend to be more tax aggressive. This result can also be seen in the negative correlation between GRI_beginner and the TTVA metric at the 5\% significance level. The correlation is evidence of an association between two variables, not controlled by other characteristics of the firms, which can simultaneously affect this relationship.

The results also suggest that CSR practices are positively correlated with leverage (LEV), capital intensity (PPE), size (SIZE) and cash level (CASH). 
Table 5

Pearson's correlations

\begin{tabular}{|c|c|c|c|c|c|c|}
\hline & BTD & TTVA & $\begin{array}{l}\text { GRI } \\
\text { high }\end{array}$ & $\begin{array}{c}\text { GRI } \\
\text { medium }\end{array}$ & $\begin{array}{c}\text { GRI } \\
\text { beginner }\end{array}$ & $\begin{array}{c}\text { GRI } \\
\text { incomplete }\end{array}$ \\
\hline BTD & 1.00 & & & & & \\
\hline TTVA & $-0,1571 * * *$ & 1.00 & & & & \\
\hline GRI_high & $-0,0094$ & $-0,099 * * *$ & 1.00 & & & \\
\hline GRI_medium & $0,0852 * * *$ & 0,0283 & $-0,099 * * *$ & 1.00 & & \\
\hline GRI_beginner & 0,0542 & $-0,068^{* *}$ & $-0,0445$ & $-0,1446 * * *$ & 1.00 & \\
\hline GRI_incomplete & $-0,0337$ & 0,0293 & $-0,0177$ & $-0,0575^{*}$ & $-0,0259$ & 1.00 \\
\hline ROA & $0,08719 * * *$ & $-0,066^{* *}$ & $-0,0056$ & $0,0504 *$ & 0,0386 & $-0,0235$ \\
\hline LEV & $-0,3146^{* * *}$ & $-0,0493$ & 0,0054 & $0,1289 * * *$ & 0,0467 & $-0,0216$ \\
\hline PPE & 0,0194 & $-0,0540^{*}$ & $0,0512 *$ & $0,0920 * * *$ & 0,0079 & $-0,0494$ \\
\hline SIZE & $0,0971 * * *$ & $-0,0415$ & 0,0221 & $0,5434 * * *$ & 0,0217 & 0,0016 \\
\hline CASH & $0,0842^{* * *}$ & $-0,0504^{*}$ & $-0,0474$ & $0,0828^{* * *}$ & $-0,0191$ & 0,007 \\
\hline \multirow[t]{2}{*}{ LOSS } & $-0,5577 * * *$ & $0,0619 * *$ & 0,0005 & $-0,0321$ & $-0,0395$ & $-0,0157$ \\
\hline & 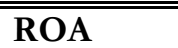 & 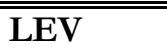 & PPE & 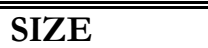 & "CASH & LOSS \\
\hline ROA & 1.00 & & & & & \\
\hline LEV & $-0,377 * * *$ & 1 & & & & \\
\hline PPE & $-0,0696 * *$ & $0,1288^{* * *}$ & 1 & & & \\
\hline SIZE & 0,0215 & $0,0962^{* * *}$ & $-0,026$ & 1 & & \\
\hline CASH & $0,1130 * * *$ & $-0,085^{* * *}$ & 0,0347 & 0,0446 & 1 & \\
\hline LOSS & $-0,663 * * *$ & $0,2541 * * *$ & 0,0147 & $-0,036$ & $-0,08 * * *$ & 1 \\
\hline
\end{tabular}

Note: Table 5 shows the Pearson correlation coefficient between the variables. Significance level of $10 \%(*), 5 \%(* *)$ and $1 \%(* * *)$. Variables that did not have a significant correlation obtained a p-value greater than 0.10 .

Note: prepared by the author, outputs from the Stata ${ }^{\circledR}$ software.

\section{Findings}

Table 6 presents the standard error and the p-value for each coefficient of each variable. To measure corporate social responsibility in Brazilian companies, dichotomous variables were used capturing advanced, intermediate, beginner and incomplete degree of CSR disclosure following the GRI guidelines while for tax aggressiveness, the book-tax-dfference (BTD) and total were used of taxes on added value (TTVA).

Table 6

Regression Results

\begin{tabular}{lcc}
\hline Variables & BTD & TTVA \\
\hline \hline GRI_high & $-0,0211^{* * *}(0.00327)$ & $-0,0819^{* * *}(0,01926)$ \\
GRI_medium & $0,1407(0,17813)$ & $-0,0087(0,02079)$ \\
GRI_beginner & $0,2404^{*}(0,13979)$ & $-0,0324(0,03647)$ \\
GRI_incomplete & $0,0018(0,00654)$ & $0,1159(0,14553)$ \\
ROA & $0,9326^{* * *}(0,03837)$ & $-0,3002(0,21098)$ \\
LEV & $-0,0296(0,27629)$ & $-0,0355(0,05657)$ \\
PPE & $-0,01364(0,02395)$ & $-0,86167(0,13817)$ \\
SIZE & $0,0093(0,0077)$ & $0,0702^{* * *}(0,02506)$ \\
CASH & $-0,2527(0,02768)$ & $0,0030(0,10628)$ \\
LOSS & $0,007(0,00575)$ & $0,0731 * *(0,03272)$ \\
Obs.: & 1081 & 1081 \\
Prob>F & 0.0000 & 0.0000 \\
\hline Note: This
\end{tabular}

Note: This Table 6 presents the coefficient, and in parentheses the standard error of the variables. $*$, ** and $* * *$ represent the significance level of $10 \%, 5 \%$ and $1 \%$, respectively. Multiple linear regression was applied for unbalanced panel data with robust errors, fixed effect by firm and year dummies (omitted in the table). The variables were 1\% winsorized in each syrup. The definitions of the variables are shown in Table 2. Fonte: prepared by the author, outputs from the Stata ${ }^{\circledR}$ software. 
The negative coefficient (-0.211) and statistically significant at the level of 1\% of GRI_advanced with BTD indicates that companies with the highest degree of disclosure of CSR practices tend to be less aggressive in taxation. This result may indicate that a greater degree of transparency in the management of the economic, social and environmental areas may inhibit more aggressive practices in order to avoid taxes on the profit of firms.

This interpretation is extracted from the arguments that the aggressive practice of tax reduction can generate a negative reputation of the firm before the steakeholders, thus, the more the firm exposes its management policies, the less it would be willing to engage in practices that can reduce reputation, being associated with the current that advocates a substitute relationship between CSR practices and tax aggressiveness (Kim, Park, \& Wier, 2012; Lanis \& Richardson, 2011; Mackey et al., 2007).

The result is in line with the study by Martinez \& Ramalho (2017), in the analysis of Brazilian ISE (Corporate Sustainability Index) companies, stating that the management of taxes downwards is not a priority on the agenda of socially responsible companies because they are less subject to tax liabilities, therefore enjoying the benefits of being less risky companies, positively impacting the cost of capital and stock appreciation.

Corroborating this interpretation, the findings by Hanlon and Slemrod (2009) show that the share price of American companies tends to fall through the publication of involvement with tax havens, with more pronounced effects on companies in the retail sector, which demonstrates the negative impact of public opinion on the company's reputation, through involvement in aggressive tax practices.

However, the analysis of tax aggressiveness only from the perspective of the BTD may not be clear enough because it captures, in addition to downward tax management, the propensity for earnings management (Martinez, 2017).

When analyzing the association with the TTVA, which calculates the effective rate of the company's total taxes, the opposite result was found. The negative and significant coefficient $(-0.0819)$ indicates that Brazilian companies with a higher GRI degree, on average, pay less taxes than the others.

This result is consistent with the findings of Garcia (2016), who after analyzing the relationship between CSR, lobbying and tax payments in US companies in the MSCI index, claim that companies that are more socially responsible obtain a greater return on their spending on lobbying than less responsible companies, thus reflecting in lower effective tax rates, thus the benefits of being socially responsible can generate profits for shareholders while fulfilling the wishes of non-owning parties.

Therefore, when analyzing tax aggressiveness from the perspective of BTD, the results show less tax aggressive CSR companies, however, when analyzing tax aggressiveness measured by the effective rate of total taxes in the Brazilian context (TTVA), the results show companies with a higher GRI degree paying less tax, indicating that companies can use the management mechanism to lower taxes and, in a complementary way, preserve their reputation, which could be explained by the fact that greater transparency and reputation of the firm can influence practices of tax favoring through lobbying (Davis, Guenther \& Krull, 2016; Hines, 2005; Landry, Deslandes \& Fortin, 2013).

Besides, statistically significant results were found in companies with the highest level of social responsibility, which represent only $2.9 \%$ of the sample, which is consistent with previous studies (Davis et al., 2016; Garcia, 2016; Huseynov \& Klamm, 2012; Landry, Deslandes, \& Fortin, 2013; Martinez \& Ramalho, 2017).

The other degrees of GRI, namely: medium, beginner and incomplete, were not associated with the tax aggressiveness metrics, except for the positive coefficient of the beginner level with BTD (0.2404) at the 10\% significance level, which shows entry-level GRI companies that are more tax-aggressive. 
In general, the high costs of engaging in corporate social responsibility can influence companies' decision to use the benefits of tax reduction and explain the null relationship between low GRI levels and tax aggressiveness (Davis, Guenther, \& Krull, 2016). The positive and significant result of the SIZE variable, which represents the size of firms, with the TTVA metric, also shows that companies prone to tax aggressiveness are larger, consistent with the characteristic of companies with a high degree of involvement in CSR.

\section{Conclusions}

This research investigated the association between companies with Corporate Social Responsibility (CSR) practices and their tax aggressiveness. The sample consisted of companies listed in Brazil, Bolsa, Balcão (B3) between the years 2010 and 2017, with a total of 1,081 observations submitted to a multiple linear regression model for panel data.

To measure the tax aggressiveness of companies, the Box-Tax Difference (BTD) metrics and Total Value Added Tax (TTVA) were used. As CSR proxies, it was considered whether or not the company published a sustainability report under the guidelines of the Global Reporting Initiative (GRI), and which level of structure was used to differentiate between higher and lower disclosure levels, with four stages being established: high, intermediate, beginner and incomplete.

The results point to a statistically significant relationship between the highest degree of CSR and tax aggressiveness. When analyzing the tax aggressiveness of companies from the perspective of BTD, it was found that companies with a high degree of CSR have higher tax burdens than others, which leads to the interpretation that the benefits of engaging in managing taxes downwards may not offset the negative reputation cost of the firm arising from this activity.

From the perspective of a metric that indicates the effective rates of total corporate taxes - TTVA - it was noted that companies with high involvement in CSR tend to pay less taxes than others. Previous studies suggest that this result may be due to companies managing the tax downward, benefiting not only shareholders, but also society, as companies with a high degree of CSR are better able to support society as they are more profitable companies.

Another possible explanation for the result, in the context of Brazilian companies, is that companies with a high degree of CSR at some point may have found in indirect taxes a mechanism to preserve their reputation and also be tax aggressive, since there would be greater perception the public in relation to the management of taxes downwards on profit than on taxes on revenue, justifying why the evidence of the relationship between CSR and tax aggressiveness is a substitute in BTD and complementary in TTVA.

The results lead us to realize that this moment can be when the company reaches a high degree of involvement with CSR, thus, these companies enjoy a lower cost of capital, share appreciation, and thus manage to meet the expectations and interests of both shareholders as much of society.

The evidence that socially responsible companies with lesser degrees of GRI disclosure do not view fiscal policy as part of the CSR agenda may be related to the Brazilian scenario, differing from international research scenarios, given the evidence that the loss of a company's reputation company would be more associated with events away from the application of aggressive tax policies, such as corruption scandals, human rights injuries and environmental disasters in which the company is involved.

The findings in this research contribute to the discussion of the type of information that is relevant in the disclosure of sustainability, pointing out that, at least for most Brazilian companies, from the results obtained, it is not expected that the payment of taxes is seen as a sustainable development agenda, as suggested by the GRI and theories on CSR. The association of CSR with fiscal policy was found in companies with an advanced degree of GRI, which represents companies that are in an extremely advanced stage of accounting information disclosure $-2.9 \%$ of the sample in this research - a reality different from most companies analyzed. 
Given that there is a need in the national literature to find more consistent CSR metrics (Nossa et al., 2017), this research added a metric to measure the different degrees in which companies are dealing with CSR, thus contributing to the literature on CSR, since future research can use the GRI for comparative studies between countries, since the GRI guidelines are widely used in the world.

It is pertinent to highlight that there are some factors that, in a certain way, limit the generalization of the results of this research: (i) the low number of observations $(1,081)$, affected by the losses with missing data or the difficulty of obtaining them, is small compared to the anecdotal evidence of the sample size of Brazilian companies, (ii) the lack of a robust indicator of greater and lesser commitment to corporate sustainability in the Brazilian scenario, as frequently used in international research, (iii) the ambiguity of the results of the aggressiveness metrics, which appear to be very sensitive to the methodological process or the proxy that is used.

Future research could broaden the horizon of observations, because although this type of approach generates loss of comparability, it would allow to improve the understanding of this theme. Like research in other countries, it could also improve the metrics for CSR by considering qualitative factors of indicators that measure CSR, for example, classifying them into positive and negative practices of each corporation, which would cover all companies and not only those that release sustainability reports. This path is still difficult in the Brazilian scenario due to the lack of access to databases that allow this verification in an operational way.

\section{References}

Crisóstomo, V. L., \& Oliveira, M. R. (2016). An Analysis of the Determinants of Corporate Social Responsibility of Brazilian Firms. Brazilian Business Review, 13(4), 72 93. https://doi.org/10.15728/bbr.2016.13.4.4

Davis, A. K., Guenther, D. A., Krull, L. K., \& Williams, B. M. (2016). Do socially responsible firms pay more taxes?. The accounting review, 91(1), 47-68.

Dunbar, A., Higgins, D., Phillips, J., \& Plesko, G. (2010). What do measures of tax aggressiveness measure. In Proceedings of the National Tax Association Annual Conference on Taxation (pp. 18-26).

Garcia, J. (2016). The influence of corporate social responsibility on lobbying effectiveness: Evidence from effective tax rates.

Gray, R., Owen, D., \& Adams, C. (1983). Accountability, financial reporting and the not-for-profit sector. British Accounting Review, 15(1), 3-23.

Global Reporting Initiative - GRI. (2011). Sustainability Reporting Guidelines. Versão 3.1. Recuperado em 29 julho, 2018, de https://www.globalreporting.org/resourcelibrary/G3.1-Guidelines-with-highlights.pdf.

Global Reporting Initiative - GRI. (2014). Diretrizes para relatório de sustentabilidade. Recuperado em 10 outubro, 2018, de https://www.globalreporting.org.

Hanlon, M., \& Heitzman, S. (2010). A review of tax research. Journal of Accounting and Economics, 50(2-3), 127-178.

Hanlon, M., \& Slemrod, J. (2009). What does tax aggressiveness signal? Evidence from stock price reactions to news about tax shelter involvement. Journal of Public Economics, 93(1-2), 126-141.

Hasan, M. M., Al-Hadi, A., Taylor, G., \& Richardson, G. (2017). Does a firm's life cycle explain its propensity to engage in corporate tax avoidance? European Accounting Review, 26(3), 469-501.

Hines JR, James R. Corporate taxation and international competition. 2005.

Huang, H. H., Lobo, G. J., Wang, C., \& Xie, H. (2016). Customer concentration and corporate tax avoidance. Journal of Banking \& Finance, 72, 184-200.

Huseynov, F., \& Klamm, B. K. (2012). Tax avoidance, tax management and corporate social responsibility. Journal of Corporate Finance, 18(4), 804-827. 
Kim, Y., Park, M. S., \& Wier, B. (2012). Is earnings quality associated with corporate social responsibility? The Accounting Review, 87(3), 761-796.

Khan, H. U. Z., Azizul Islam, M., Kayeser Fatima, J., \& Ahmed, K. (2011). Corporate sustainability reporting of major commercial banks in line with GRI: Bangladesh evidence. Social Responsibility Journal, 7(3), 347-362.

Kubick, T. R., Lynch, D. P., Mayberry, M. A., \& Omer, T. C. (2014). Product market power and tax avoidance: Market leaders, mimicking strategies, and stock returns. The Accounting Review, 90(2), 675-702. Landry, S., Deslandes, M., \& Fortin, A. (2013). Tax aggressiveness, corporate social responsibility, and ownership structure.

Lanis, R., \& Richardson, G. (2011). The effect of board of director composition on corporate tax aggressiveness. Journal of Accounting and Public Policy, 30(1), 50-70.

Loebbecke, J. K., Eining, M. M., \& Willingham, J. J. (1989). Auditors experience with material irregularities-frequency, nature, and detectability. Auditing-A Journal of Practice \& Theory, 9(1), 1-28.

Mackey, A., Mackey, T. B., \& Barney, J. B. (2007). Corporate social responsibility and firm performance: Investor preferences and corporate strategies. Academy of management review, 32(3), 817-835.

Madalena, J. D., Rover, S., Ferreira, D. M., \& Ferreira, L. F. (2016). Estudo dos relatórios de sustentabilidade GRI de empresas brasileiras. Revista Eletrônica em Gestão, Educação e Tecnologia Ambiental, 20(1), 566-579.

Martinez, A. L. (2017). Agressividade tributária: um survey da literatura. Revista de Educação e Pesquisa em Contabilidade (REPeC), 11.

Martinez, A. L., \& Martins, V. A. M. (2016). Alavancagem financeira e agressividade fiscal no Brasil. Revista de Contabilidade da UFBA, 10(3), 4-22.

Martinez, A. L., \& Ramalho, V. P. (2017). Agressividade tributária e sustentabilidade empresarial no Brasil. Revista Catarinense da Ciência Contábil, 16(49).

Martinez, A. L., \& Salles, A. F. (2018). Agressividade tributária e cash holdings: Um estudo das companhias abertas brasileiras. Revista de Contabilidade da UFBA, 12(3), 4-23.

Mocivuna, I. N., Thompson, C. D., \& Silva, J. R. (2019). O Propósito Negocial como Critério de Validade de Planejamentos Tributários, segundo o Entendimento do CARF. Revista Licen On-Line, 9(1), 27-45.

Motta, F., \& Martinez, A. (2015). Agressividade fiscal em sociedades de economia mista. Anais da Enanpad, Belo Horizonte, MG, Brasil, 39.

Nossa, V., Rodrigues, V. R., \& Nossa, S. N. (2017). O que se tem pesquisado sobre Sustentabilidade Empresarial e sua Evidenciação? Revista de Educação e Pesquisa em Contabilidade (REPeC), 11.

Orsato, R. J., Garcia, A., Mendes-Da-Silva, W., Simonetti, R., \& Monzoni, M. (2015). Sustainability indexes: why join in? A study of the 'Corporate Sustainability Index (ISE)'in Brazil. Journal of Cleaner Production, 96, 161-170.

Pereira, A., Stocker, F., Mascena, K., \& Boaventura, J. (2020). Corporate Social Performance and Financial Performance in Brazilian Companies: Analysis of the Influence of Disclosure. Brazilian Business Review. Retrieved from http://bbronline.com.br/index.php/bbr/article/view/602

Schepers, S. (2010). Business-government relations: beyond lobbying. Corporate Governance: The international journal of business in society, 10(4), 475-483.

Slemrod, J. (2004). The economics of corporate tax selfishness (No. w10858). National Burean of Economic Research.

Waller, D. S., \& Lanis, R. (2009). Corporate social responsibility (CSR) disclosure of advertising agencies: an exploratory analysis of six holding companies' annual reports. Journal of Advertising, 38(1), 109-122.

Weber, O., Koellner, T., Habegger, D., Steffensen, H., \& Ohnemus, P. (2008). The relation between the GRI indicators and the financial performance of firms. Progress in Industrial Ecology, an International Journal, 5(3), 236-254. 